\title{
Problematyka przywrócenia migracji ryb przez obiekty hydrotechniczne w korytach rzecznych
}

\author{
Aspects of the fish migration trough barrages restoration in river channels
}

\author{
Michał Wierzbicki \\ Katedra Inżynierii Wodnej i Sanitarnej, Uniwersytet Przyrodniczyw Poznaniu, Poznań, mwierzb@up.poznan.pl
}

Zarys treści: W artykule poruszono problematykę przywrócenia migracji ryb przez obiekty hydrotechniczne w aspekcie oddziaływania piętrzenia na morfologię koryta. Omówiono zmiany jakie mogą nastąpić w korycie rzeki na skutek piętrzenia wody i jej wykorzystania dla celów energetycznych, oraz wpływ, jaki piętrzenie wywiera na warunki migracji organizmów wodnych, głównie ryb. Przedstawiono priorytety oraz założenia projektowe, które powinny spełniać współczesne konstrukcje przepławek tak, aby ich działanie było jak najbardziej efektywne. Na podstawie prac związanych z opiniowaniem dokumentacji projektowych oraz wniosków o dofinansowanie budowy przepławek ustalono, jakie elementy powinny być brane pod uwagę podczas opracowywania koncepcji, projektu oraz użytkowania przyjętego rozwiązania udrożnienia stopnia dla migracji organizmów. Wskazano na potrzebę rzetelnej analizy uwarunkowań formalnoprawnych, środowiskowych i technicznych oraz różnych wariantów rozwiązań.

Słowa kluczowe: piętrzenie, morfologia koryta, elektrownia wodna, migracja ryb, przepławka

\begin{abstract}
In this paper aspects of the fish migration trough barrages in context of the barrage influence on river morphology are presented. River morphology changes as the result of the artificial water level increasing and water usage for the power plant are described. Also the barrage influence on fish migration conditions is presented. Fishpass projects priorities and foundations that should be fulfilled to get maximum efficiency are discussed in this paper. On the basis of applications for providing finances of fishpass projects and their realizations, aspects that should be taken into consideration during the conception, project elaborating and the fishpass utilization are specified. The necessity of law regulations and environment and technical aspects adequate analyse is emphasized. Also different versions of available solutions should be analysed.
\end{abstract}

Key words: barrage, river morphology, water power plant, fish migration, fishpass

\section{Wpływ piętrzenia wody na zmiany w korycie rzeki}

W korytach naturalnych, na całej długości ich biegu, topografia dna i układ poziomy są rezultatem złożonego, wzajemnego oddziaływania przepływu wody, brzegów koryta oraz ruchu rumowiska. Ponieważ charakter rzeki uzależniony jest od wielu wzajemnie ze sobą powiązanych czynników hydrologicznych, hydraulicznych i morfologicznych, należy pamiętać, że każda zmiana warunków przepływu wody (np. prędkości, stanu wody) może pociągnąć za sobą nieodwracalne zmiany nie tylko w korycie, ale również $\mathrm{w}$ dolinie rzeki.
Piętrzenie wody (dla celów energetycznych, progami stabilizującymi itp.) istotnie oddziałuje na procesy morfologiczne zachodzące w korycie rzeki. Jest to szczególnie wyraźnie widoczne w przypadku obiektów hydrotechnicznych piętrzących wodę dla potrzeb produkcji energii w małych elektrowniach wodnych (MEW), gdzie dąży się do jak największego wykorzystania energii przepływającej wody. Oddziaływanie na środowisko obiektów hydrotechnicznych piętrzących wodę odbywa się zarówno na etapie ich budowy, eksploatacji, jak i likwidacji. Ze względu na długofalowość najistotniejsze jest oddziaływanie na etapie eksploatacji, które wpływa na zmiany morfologiczne w korycie rzeki powyżej i poniżej piętrzenia, zmienia hydrau- 
likę przepływu wody w rzece, może powodować zmiany $\mathrm{w}$ jej reżimie hydrologicznym poprzez zmianę wielkości przepływu wody w czasie, a także wywołuje zmiany w ekosystemie rzeki, oddziałując na elementy biologiczne i parametry fizykochemiczne (Lessard, Heyes 2003, Radke $i$ in. 2012). Niezwykle ważnym aspektem oddziaływania obiektów hydrotechnicznych piętrzących wodę jest przerwanie ciągłości migracji organizmów (głównie ryb) poprzez fizyczny brak możliwości pokonania bariery. Piętrzenie wody stanowi dla migrujących organizmów niemożliwą do pokonania przeszkodę. W celu zachowania ciągłości migracji w górę rzeki (wstępującej) i w dół rzeki (zstępującej), konieczne jest wykonanie urządzenia wodnego, które umożliwi pokonanie stopnia.

\section{Zmiany w hydraulice i morfologii koryta}

Na całej długości rzeki występuje nieprzerwany wpływ płynącej wody na nieruchome dno i brzegi. Wpływ ten objawia się procesami erozji, transportu i akumulacji rumowiska. Materiał dna bądź brzegów koryta rzecznego zostaje na skutek działania płynącej wody oderwany (erozja), następnie przenoszony (transport) i ostatecznie zdeponowany w innym miejscu (akumulacja) (Klimaszewski 2005). Morfologia koryta jest kształtowana przez ruch wody oraz sposób uruchomienia, transportu i odkładania rumowiska, a zależy głównie od prędkości przepływu wody, charakterystyki rumowiska, materiału dna i brzegów oraz roślinności (Przedwojski 1998, Popek 2006). Jednym ze skutków transportu rumowiska dennego jest tworzenie się charakterystycznych dla danych warunków form dennych oraz korytowych (Przedwojski 1998, Radecki-Pawlik 2011). Należy wyraźnie podkreślić, że każda ingerencja w korycie rzeki zmieniająca elementy wpływające na procesy jego kształtowania generuje zmiany w jego morfologii (Kondolf 1997).

Budowa każdego stopnia wodnego zaburza stan równowagi koryta rzecznego. Na skutek piętrzenia wody powyżej stopnia/MEW występuje zjawisko cofki - podniesienia się zwierciadła wody w rzece, które wpływa na zmiany warunków hydraulicznych (prędkość przepływu wody) i procesów morfologicznych (transport rumowiska rzecznego, procesy korytotwórcze) w korycie rzeki, sięgając nawet wielu kilometrów w górę rzeki. Podniesienie poziomu zwierciadła wody skutkuje przede wszystkim zmianą spadku zwierciadła i zmniejszeniem prędkości przepływu, co powoduje zmianę charakteru przepływu wody. W skrajnych przypadkach (niski przepływ i sztucznie utrzymywany wysoki stan) może nastąpić przejście $z$ ruchu turbulentnego do ruchu laminarnego, w którym ruch wody odbywa się bez mieszania, warstwowo. Jest to szczególnie widoczne w przypadku zaporowych zbiorników wodnych bądź elektrowni derywacyjnych, gdzie większość przepływu prowadzona jest przez kanał MEW, natomiast niewielką jego część (na ogół równą przepływowi nienaruszalnemu) przeprowadza się korytem rzeki w warunkach spiętrzonego zwierciadła wody. Wtedy możliwe jest wystąpienie sytuacji całkowitej zmiany naturalnego charakteru przepływu wody w korycie rzeki.

W przypadku przegrodzenia koryta rzeki budowlą piętrzącą następuje zmiana warunków jednego z podstawowych czynników kształtujących systemy fluwialne transportu rumowiska rzecznego, głównie wleczonego. Przegrodzenie koryta rzeki i spiętrzenie zwierciadła wody doprowadza do zakłócenia, a nawet przerwania, ciągłości ruchu rumowiska i zachwiania równowagi dynamicznej w korycie rzeki. Skutkiem tego jest proces akumulacji powyżej stopnia i proces erozji dna oraz brzegów rzeki poniżej stopnia.

W zasięgu oddziaływania piętrzenia rumowisko podlega wpływom hydrodynamicznym zmieniającym się w kierunku przepływu. Wraz ze zmniejszaniem się prędkości przepływu wody w cofce następują zmiany w procesie transportu rumowiska rzecznego, które zaczyna być akumulowane powyżej piętrzenia. Należy podkreślić, że proces akumulacji nie przebiega jednakowo i jest zmienny w czasie i przestrzeni. Ze względu na zależność ruchu cząsteczki rumowiska od energii poruszającego ją strumienia, rumowisko unoszone w górnej części może przyjąć formę rumowiska wleczonego (Popek 2006). Powolnemu zmniejszaniu prędkości przepływu wody w danym przekroju rzeki towarzyszy sortowanie według wielkości ziaren transportowanego materiału, od grubszego do coraz drobniejszego.

Analizując proces akumulacji, należy zwrócić uwagę na to, że odkładanie się transportowanego materiału może postępować w górę rzeki. W zależności od warunków hydraulicznych i morfologicznych transportowane rumowisko deponowane jest głównie w górnej części zasięgu cofki piętrzenia (Przedwojski i in. 2008). Nagromadzone osady mogą powodować zmniejszenie głębokości w miejscu deponowania, jednocześnie podpiętrzając zwierciadło wody w górze rzeki. W związku z tym kolejne partie niesionego materiału są częściowo przetaczane $\mathrm{w}$ dół ku piętrzeniu, a częściowo odkładane na wydłużającym się w górę odcinku cofki - proces odkładania się rumowiska będzie postępował w górę rzeki (Dysarz i in. 2006). W przypadku gdy rzeka spiętrzona jest jazem, zaś woda robocza prowadzona jest do elektrowni kanałem derywacyjnym, którego wlot umieszczony jest obok jazu, następuje zarówno swoisty podział wody na dwa strumienie, jak i podział rumowiska na dwie części, z których jedna osadza się w rzece, a druga w kanale, wraz ze zmianą ilości wody przepuszczanej przez jaz i wprowadzanej do kanału.

Zmiana warunków hydraulicznych powyżej piętrzenia będzie skutkowała również zmianami form dennych charakterystycznymi dla danego odcinka rzeki. Ponadto spowolnienie przepływu wody może doprowadzić do zintensyfikowania procesu zarastania koryta, skutkując zwiększeniem szorstkości generującym wzrost oporów przepływu wody. Zmiana w strukturze roślinności wodnej pociąga za sobą zmianę warunków hydraulicznych przepływu wody, oddziałując na rozkład prędkości na głębokości i szerokości koryta rzecznego. To z kolei może wpłynąć na dalsze zmniejszenie zdolności do transportu rumowiska 
i zintensyfikowanie procesu akumulacji. Powyżej stopnia nastąpi zakłócenie naturalnej zależności stan/przepływ wody nie tylko na skutek samego piętrzenia, ale również w wyniku procesów korytowych związanych ze zmianami warunków przepływu wody - akumulacją rumowiska i zarastaniem koryta. Dlatego powyżej piętrzenia nastąpi istotna zmiana warunków przepływu wód wezbraniowych (Przedwojski i in. 2007).

Ważnym zjawiskiem dotyczcym piętrzenia jest intensywna erozja denna poniżej budowli piętrzącej. Piętrzenie wody narusza równowagę ciągłości przepływu rumowiska wleczonego (zmniejszenie/zatrzymanie transportu rumowiska), a działanie elementów stopnia (jaz, MEW) powoduje zwiększenie energii wypływającej wody i koncentrację przepływu. Zmiany wywołane procesem erozji uwidaczniają się w przeobrażeniach układu dna koryta zarówno w profilu podłużnym, jak i w przekrojach poprzecznych. Proces erozji powoduje powstanie wyboju miejscowego bezpośrednio poniżej wypadu z urządzeń upustowych, a także systematyczne obniżanie się poziomu dna na coraz dłuższym odcinku rzeki. Ma ona charakter trwały i w miarę upływu czasu obejmuje swym zasięgiem coraz dłuższy odcinek, który po latach może osiągnąć wiele kilometrów (Wierzbicki i in. 2008). Efektem jest początkowo dość szybkie, następnie wolniejsze, lecz ciągłe obniżanie się dna rzeki i związane $\mathrm{z}$ tym obniżanie się poziomu zwierciadła wody w korycie, zmniejszenie się spadku podłużnego rzeki, zmiany $\mathrm{w}$ uziarnieniu rumowiska (Wierzbicki $\mathrm{i}$ in. 2008) oraz zmiany w układzie wód gruntowych i ciągłości morfologicznej z dopływami.

Zmodyfikowane warunki hydrauliczne poniżej piętrzenia mogą wpłynąć na zmianę form dennych charakterystycznych dla danego odcinka rzeki. Proces erozji poniżej piętrzenia jest dodatkowo czynnikiem decydującym o zmianach uziarnienia rumowiska dennego w korycie. Wody wypływające z turbin MEW i urządzeń upustowych usuwają drobniejszy materiał, powodując powstanie zjawiska obrukowania dna (Wierzbicki, Wicher 2002). Na skutek tego procesu materiał dna staje się gruboziarnisty i mało zróżnicowany.

Efektem procesu erozji poniżej piętrzenia jest również zakłócenie naturalnej zależności stan/przepływ. W efekcie tych zmian poniżej piętrzenia stany wody przy danych przepływach ulegną obniżeniu - krzywa przepływów przesuwa się „w dół” (Wicher i in. 2002, Wierzbicki i in. 2008). Podobnie jak w przypadku procesu akumulacji zmiana tej zależności nie będzie jednorazowa, lecz rozłożona w czasie i zależna od zmian morfologicznych w korycie rzeki (dynamiki procesu erozji). Ponieważ proces erozji ma charakter trwały i w miarę upływu czasu obejmuje swym zasięgiem coraz dłuższy odcinek rzeki, dodatkowo może doprowadzić do zakłócenia łączności morfologicznej z dopływami poniżej piętrzenia.

\section{Elementy biologiczne}

Piętrzenia związane z hydroenergetyką niszczą ciągłość podłużną rzeki, zakłócając przepływ energii, materii i ge- nów. Jest to nie tylko szkodliwe dla ryb, które są odcinane od tarlisk, żerowisk i zimowisk, ale i innych organizmów. Organizmy wolno wędrujące, np. małże lub raki, także nie są w stanie sforsować przegrody. Nawet stojąca woda w zbiorniku lub bardzo wolno płynąca woda w korycie rzeki może stanowić barierę behawioralną dla ryb reofilnych powodując rozcięcie populacji. Każde piętrzenie modyfikuje morfologię koryta rzecznego. Przekształcenia morfologii koryta powyżej piętrzenia oraz poniżej piętrzenia $\mathrm{w}$ istotny sposób zmieniają naturalne warunki migracji organizmów, gdyż pierwotne mezo- i mikrosiedliska zanikają lub zmieniają się ich proporcje (Lessard, Heyes 2003). Należy również wskazać, że wbrew powszechnemu przekonaniu turbiny elektrowni wodnych nie natleniają wody, a nawet, jeśli są zasilane ze zbiorników zaporowych, mogą pogorszyć warunki tlenowe w rzece.

Do zmienionych warunków hydrologicznych i morfologicznych dostosowują się biocenozy, stopniowo coraz bardziej różniące się od tych, które pierwotnie występowały w naturalnej rzece. Tempo tych zmian zależy nie tylko od skali odkształceń hydromorfologicznych, ale również od wrażliwości występujących gatunków oraz stopnia naturalności rzeki przed budową piętrzenia - najszybciej zareagują systemy naturalne lub zbliżone do naturalnych.

Oddziaływania piętrzeń na zespoły fauny dobrze udokumentowane są w stosunku do gatunków ryb. Naturalne populacje ryb przez tysiące lat ewoluowały w swoich unikalnych ekosystemach, w specyficznych dla każdej rzeki warunkach morfologicznych i reżimie hydrologicznym. Stąd w dużych systemach rzecznych występuje często jeden genotyp dla każdego dopływu, który ma swoją własną strategię migracyjną, żerowania, wzrostu itd., wypracowaną dla własnego systemu (Verspoor 1997). Z tego powodu ryby są szczególnie wrażliwe na wszelkie odkształcenia hydromorfologiczne. Zmniejszenie szybkości przepływu w cofce piętrzenia powoduje, że ta część rzeki staje się nieprzydatna do bytowania gatunków reofilnych, które zastępowane są gatunkami stagnofilnymi. W przypadku rzeki jest to traktowane jako degradacja struktury ichtiofauny. Dobrym przykładem całkowitej zmiany struktury gatunkowej ryb w cofce piętrzenia jest Wisła w Krakowie. Podpiętrzenie spowodowane stopniem wodnym Dąbie przyczyniło się do zniknięcia pstrągów, świnki, brzany - ich miejsce zajęły leszcze (Włodek, Skóra 1993). Drugim ważnym powodem zmian struktury ichtiofauny lub jej zaniku są fizyczne trudności w pokonaniu barier poprzecznych. Na zanik ryb w potokach kluczowy wpływ mają nawet małe progi wodne (Bylak i in. 2009, Kukuła 2011).

\section{Środki minimalizujące wpływ piętrzenia na migrację ryb}

Działania eliminujące lub ograniczające negatywny wpływ odnoszą się do samego przedsięwzięcia i jego charakterystyki. Mają one na celu taką zmianę cech inwesty- 
cji (piętrzenia, elektrowni lub urządzeń spustowych), aby sprowadzić oddziaływania do poziomu co najwyżej mało znaczącego. Najlepiej byłoby, gdyby środki łagodzące doprowadziły do całkowitej eliminacji negatywnych skutków, ale taka sytuacja w praktyce jest niezwykle rzadka. Ograniczenie oddziaływania stopnia piętrzącego (np. stopień z MEW) na warunki migracji organizmów w rzece należy rozpatrywać w kontekście kompleksowych rozwiązań łączących zastosowanie różnych środków.

\section{Gospodarowanie wodą na obiekcie hydrotechnicznym}

Analizując wpływ piętrzenia i działania MEW na hydraulikę i morfologię rzeki, należy podkreślić znaczenie właściwej gospodarki wodnej na obiekcie. Odpowiedni rozdział przepływu wody w rzece na poszczególne elementy stopnia powinien uwzględniać nie tylko potrzeby energetyczne, ale również zjawiska towarzyszące piętrzeniu. Gospodarowanie wodą (zmiany poziomu piętrzenia, rozdział przepływu wody) powinno uwzględniać wpływ, jakie dane działanie wywiera na warunki przepływu wody powyżej i poniżej piętrzenia. Z punktu widzenia działania MEW logiczne jest, że przez turbiny przeprowadzana być powinna jak największa część przepływu. Należy jednakże podkreślić, że rozdział wody powinien uwzględniać w pierwszej kolejności zapewnienie potrzeb biologicznych koryta rzeki (przepływ nienaruszalny, ciągłość migracji - praca przepławki), a następnie pokrycie potrzeb MEW z uwzględnieniem przepustowości turbin (minimalna i maksymalna) i możliwości utrzymania poziomu piętrzenia w danych warunkach hydrologicznych. Szczególnego znaczenia nabiera to w wypadku elektrowni derywacyjnych, gdzie zmniejszenie przepływu wody w rzece może wystąpić nawet na dłuższym jej odcinku. Wtedy należy ze szczególną uwagą przeanalizować konieczność zapewnienia odpowiedniej ilości wody w celu zaspokojenia biologicznych potrzeb wodnych w korycie rzeki.

\section{Środki ograniczające śmiertelność ryb w turbinach}

Ta grupa rozwiązań ma na celu niedopuszczenie do dostania się migrujących ryb do turbin MEW bądź urządzeń upustowych stopnia, głównie w przypadku migracji w dół rzeki (zstępującej). Wyróżnić tutaj można: zabezpieczenia mechaniczne stałe, zabezpieczenia mechaniczne ruchome, bariery behawioralne.

Zabezpieczenia mechaniczne stałe są stosowane przed wlotami do turbin od strony wody górnej oraz poniżej wylotów z turbin od strony wody dolnej. Urządzenia te można podzielić na: kraty ochronne, ekrany kierujące, bariery oprowadzające i bariery ochronne. Zabezpieczenia mechaniczne ruchome są lokalizowane przy większych elektrowniach przed wlotami do turbin od strony wody górnej i mogą mieć postać obrotowych walców lub pionowych taśmociągów z perforowaną powierzchnią, czyszczącą się samoczynnie $\mathrm{w}$ trakcie wykonywania obrotów. Z kolei zadaniem barier behawioralnych jest takie oddziaływanie na zachowanie ryb, aby kierowały się do stref umożliwiających im dalszą wędrówkę (urządzeń migracyjnych). Do tego typu rozwiązań można zaliczyć: bariery żaluzjowe, bariery akustyczne, bariery świetlne, kurtyny sprężonego powietrza, bariery łańcuchowe, bariery elektryczne.

\section{Urządzenia służące migracji ryb}

Analizując umożliwienie migracji ryb przez stopień wodny należy podkreślić fakt, że warunki migracji wstępującej i zstępującej nie są jednakowe, gdyż dotyczyć mogą różnych gatunków ryb w różnych stadiach rozwojowych (dojrzałe łososie migrujące $\mathrm{w}$ górę rzeki na tarło i smolty łososia migrujące w dół rzeki) i w różnych okresach (różnych warunkach hydrologicznych). Dotychczas przyjmowano, że urządzenia służące migracji umożliwiają pokonanie przegrody podczas wędrówki w górę rzeki. Obecnie należy budować dwufunkcyjne urządzenia do migracji w obu kierunkach lub dwa odrębne urządzenia do tego celu: przepławkę do migracji wstępujących i przelew migracyjny do migracji zstępujących.

Jako możliwą drogę migracji zstępującej przez stopień wodny można wymienić (ryc. 1): komorę turbin, przelewy urządzeń hydrotechnicznych, przelewy migracyjne, specjalne urządzenia obejściowe, niektóre typy przepławek, rozwiązania nietypowe. Najlepszą efektywnością charakteryzują się dobrze zlokalizowane i zaprojektowane przelewy migracyjne, specjalne urządzenia obejściowe, niektóre typy przepławek, do których są kierowane lub oprowadzane ryby wędrujące $w$ dół rzeki. $Z$ kolei jako drogę migracji wstępującej przez stopień wodny można wskazać jedynie przepławki i rozwiązania nietypowe (ryc. 1). Dobór urządzenia i jego rozwiązania projektowe oraz działanie zależne są od rodzaju i wymogów środowiskowych ryb, warunków hydrologicznych, warunków

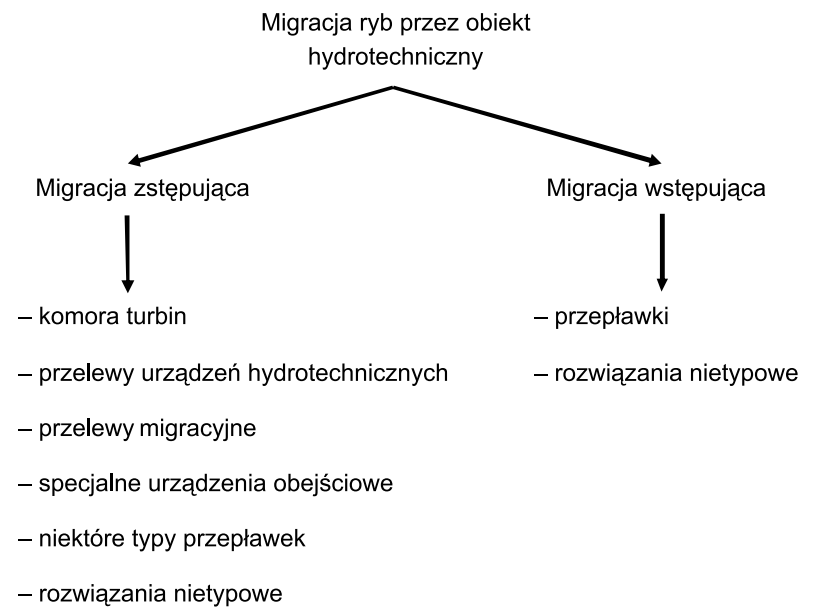

Ryc. 1. Możliwe drogi migracji ryb przez piętrzenie z małą elektrownią wodną (MEW)

Fig. 1. Possible fish migration paths trough barrage with water power plant 
morfologicznych, parametrów technicznych urządzeń, rozdziału wody w węźle.

W wypadku doboru rozwiązania urządzenia umożliwiającego migrację przez stopień wodny trzeba brać pod uwagę wiele istotnych aspektów, takich jak: optymalna lokalizacja, wejście (wylot wody) od strony dolnej wody, warunki prądu wabiącego, wyjście (wlot wody) od strony górnej wody, przepływ wody i warunki hydrauliczne w przepławce, parametry geometryczne przepławki, dno przepławki, czas (terminy) pracy, utrzymanie i konserwacja przepławki, monitoring efektywności działania, integracja $z$ otoczeniem. Przede wszystkim powinno się uwzględniać cechy gatunkowe oraz możliwości i potrzeby ryb. Stąd, najogólniej, parametry geometryczne (rozmiary) przepławek należy projektować z uwzględnieniem największych migrujących $\mathrm{w}$ danej rzece ryb, natomiast parametry hydrauliczne $\mathrm{z}$ uwzględnieniem najsłabszych. Przy projektowaniu przepławek trzeba również wziąć pod uwagę zmienne warunki hydrologiczne i morfologiczne danej rzeki i danego przekroju oraz terminy migracji ryb. Przepławka musi funkcjonować w ciągu całej doby, a ewentualne ograniczenia pracy mogą wystąić jedynie w wypadku wystąpienia przepływów ekstremalnych oraz podczas prac remontowych, które mogą być prowadzone tylko poza okresami migracyjnymi. Ponieważ przepławki są konstrukcjami sztucznie wykonanymi, istnieje potrzeba właściwej integracji $\mathrm{z}$ otoczeniem (korytem $\mathrm{i}$ doliną rzeki), stąd powinno się stosować materiały naturalne i lokalne, zapewniając połączenie z korytem rzeki, wkomponowanie w krajobraz z jednoczesnym zabezpieczeniem konstrukcji przed dewastacją i kłusownictwem.

Jako podstawowy dla analizy możliwości udrożnienia piętrzenia pod kątem migracji należy przyjąć fakt, że zdolność rozpoznawania kierunku nurtu i rozkładu prędkości w strumieniu wody przez organizmy wodne odgrywa decydującą rolę $\mathrm{w}$ ich orientacji w rzekach (Wiśniewolski i in. 2008). Stąd maksymalizacja efektywności funkcjonowania przepławki polega na przyjęciu takiego rozwiązania, które umożliwi migrację różnych gatunków i osobników w zmiennych warunkach przepływu wody przez stopień. Przy projektowaniu przepławek należy uwzględniać terminy migracji ryb, a także zmienne warunki hydrologiczne oraz morfologię koryta charakterystyczne dla danej rzeki i danego przekroju. Ewentualne ograniczenia pracy przepławki mogą wystąpić tylko w wypadku wystąpienia przepływów ekstremalnych, choć należy pamiętać, że to właśnie wezbrania są impulsem podejmowania wędrówek wstępujących przez wiele gatunków.

Lokalizacja przepławki maksymalizująca efektywność jej funkcjonowania uwarunkowana jest kierunkiem migracji ryb $\mathrm{w}$ korycie rzeki (migracja $\mathrm{w}$ górę rzeki i w dół rzeki). W związku z tym lokalizacja przepławki:

- powinna być uzależniona od kierunku drogi ryb w korycie określonego na podstawie obserwacji,

- powinna być uzależniona od kształtowania się linii nurtu w korycie - tam, gdzie występuje najsilniejszy prąd,

- dla stopnia z elektrownią wodną po stronie EW,

- jak najbliżej zapory bądź wylotu z turbin,
- dla stopnia usytuowanego ukośnie na brzegu kąta ostrego,

- dla stopnia MEW z kanałem derywacyjnym może zachodzić konieczność wykonania dwóch przepławek, aby zapewnić migrację przez kanał i rzekę (lokalizacja przy EW i na stopniu kanału).

Wylot wody z przepławki (wejście) od strony dolnej wody decyduje o możliwości odnalezienia przepławki i wejścia do niej przez migrujące w górę rzeki organizmy. W związku z tym wylot wody z przepławki powinien:

- być zlokalizowany w strefie koncentrowania się ryb określonej na podstawie obserwacji,

- zapewniać wejście przy zmiennych stanach wody, co wymusza dokładną analizę warunków przepływu wody na dolnym stanowisku,

- być jasny - oświetlony najlepiej światłem dziennym,

- być widoczny dla ryb migrujących przy brzegu i w korycie - może zachodzić konieczność wykonania kilku wejść w planie,

- o geometrii umożliwiającej wejście organizmów różnej wielkości,

- być zlokalizowany na granicy turbulencji na wypadzie jazu/MEW i umożliwiać wejście rybom gromadzącym się przy wylocie z turbin oraz migrującym przy dnie,

- być usytuowany najlepiej równolegle do nurtu rzeki (brak zmiany kierunku płynięcia ryb) bądź pod kątem $30^{\circ}$ do nurtu rzeki (niekorzystne jest wykonanie prostopadłego wylotu wody),

- zapewniać odpowiednią wielkość przepływu gwarantującą potrzebne parametry prądu wabiącego,

- być wyposażony w zamknięcie umożliwiające wykonywanie niezbędnych napraw i prac konserwacyjnych.

Uzyskiwany poprzez wypływ wody z przepławki na dolne stanowisko stopnia prąd wabiący jest elementem decydującym o możliwości odnalezienia wejścia do przepławki, i co za tym idzie, o pokonaniu stopnia wodnego. Stąd prąd wabiący winien być:

- wyczuwalny (szczególnie w strefach sprzyjających migracji), tzn. konkurencyjny w stosunku do przepływu wody w korycie,

- o prędkości większej niż w korycie, jednakże mieszczącej się w granicach możliwości pływackich migrujących gatunków.

Należy wyraźnie podkreślić, że ze względu na kluczową rolę parametry prądu wabiącego powinny być tak dobrane, aby wabienie ryb było możliwe w jak największym zakresie przepływów (zmiany przepustowości turbin, przepuszczanie wody przez inne niż MEW elementy stopnia) oraz stanów wody.

Z kolei warunki hydrauliczne przepływu wody w przepławce oraz jej geometria decydują o możliwości pokonania przepławki przez ryby. Dobór konstrukcji, parametrów geometrycznych oraz hydraulicznych powinien uwzględniać cechy gatunkowe i możliwości pływackie ryb, stąd:

- całkowity dostępny przepływ musi być kierowany do przepławki celem zapewnienia jej pracy, a woda do 
zasilania przepławki może być pobierana tylko z danej rzeki,

- należy zapewnić zachowanie minimalnej głębokości przepływu wody w różnych warunkach hydrologicznych,

- powinno się zapewnić nieprzekraczanie w każdym punkcie przepławki maksymalnej możliwej do pokonania przez najsłabsze organizmy prędkości przepływu wody,

- maksymalna różnica poziomów wody pomiędzy basenami nie powinna być większa niż $0,2 \mathrm{~m}$ (DVWK 2002),

- w przepławce należy zapewnić odpowiednie rozproszenie (dyssypację) energii płynącej wody, zakładając nieprzekraczanie wartości 150 (200) $\mathrm{W} \mathrm{m}^{-3}$ w każdej komorze przepławki (DVWK 2002) oraz dodatkowo zapewniając tzw. baseny spoczynkowe, gdzie wielkość rozproszenia energii nie powinna przekraczać 50 W m ${ }^{-3}$ (DVWK 2002), w których migrujące organizmy będą miały możliwość przerwania pokonywania przepławki i odpoczynku,

- przepławka powinna umożliwić bezpieczne przepuszczenie wód powodziowych.

Dla skuteczności funkcjonowania przepławki ma również znaczenie wlot wody (wyjście z przepławki) od strony górnej wody. Powinien on zapewnić z jednej strony zasilanie przepławki (niezakłócony dopływ wody), a z drugiej bezpieczne wyjście organizmów migrujących w górę rzeki i wejście organizmów migrujących w dół rzeki. W związku z tym wlot wody do przepławki powinien:

- zapewnić odpowiedni przepływ i prędkości przepływu wody z uwzględnieniem możliwości pływackich różnych gatunków,
- zapewnić bezpieczne wyjście bez możliwości spłynięcia ryb do wlotu turbin bądź do pracującego jazu,

- zapewnić odpowiednią głębokość zwłaszcza w wypadku wahań poziomu piętrzenia,

- umożliwić wyjście i wejście rybom migrującym przy dnie,

- być wyposażony w zamknięcie umożliwiające zamknięcie dopływu wody i wykonywanie niezbędnych napraw i prac konserwacyjnych.

Nie bez znaczenia jest również charakter dna w przepławce, które powinno być wyłożone substratem naturalnym i charakterystycznym dla rzeki, szorstkie, o zróżnicowanej granulacji na całej długości, odporne na erozję i uszkodzenia, różnicujące rozkład prędkości w pionie i ułatwiające migrację niewielkich osobników dzięki elementom (kamieniom) umożliwiającym chowanie się oraz migrację przy dnie.

Dobrą praktyką jest prowadzenie monitoringu skuteczności działania przepławki polegającego na kontroli ilościowej i jakościowej organizmów pokonujących przepławkę. Możliwe jest, że wyniki monitoringu wymuszą poprawę skuteczności działania przepławki.

Przepławki można podzielić na urządzenia naśladujące warunki naturalne (przepławki seminaturalne), urządzenia techniczne (przepławki techniczne) i rozwiązania nietypowe. Na rycinie 2 przedstawiono ogólny podział przepławek.

Każdorazowo (nawet w przypadku likwidacji piętrzenia) udrożnienie stopnia uniemożliwiającego migrację organizmów wodnych powinno być poprzedzone koncepcją uwzględniającą wnikliwą analizę uwarunkowań formalnoprawnych, środowiskowych, technicznych oraz różnych możliwych do realizacji wariantów. Uwarunko-

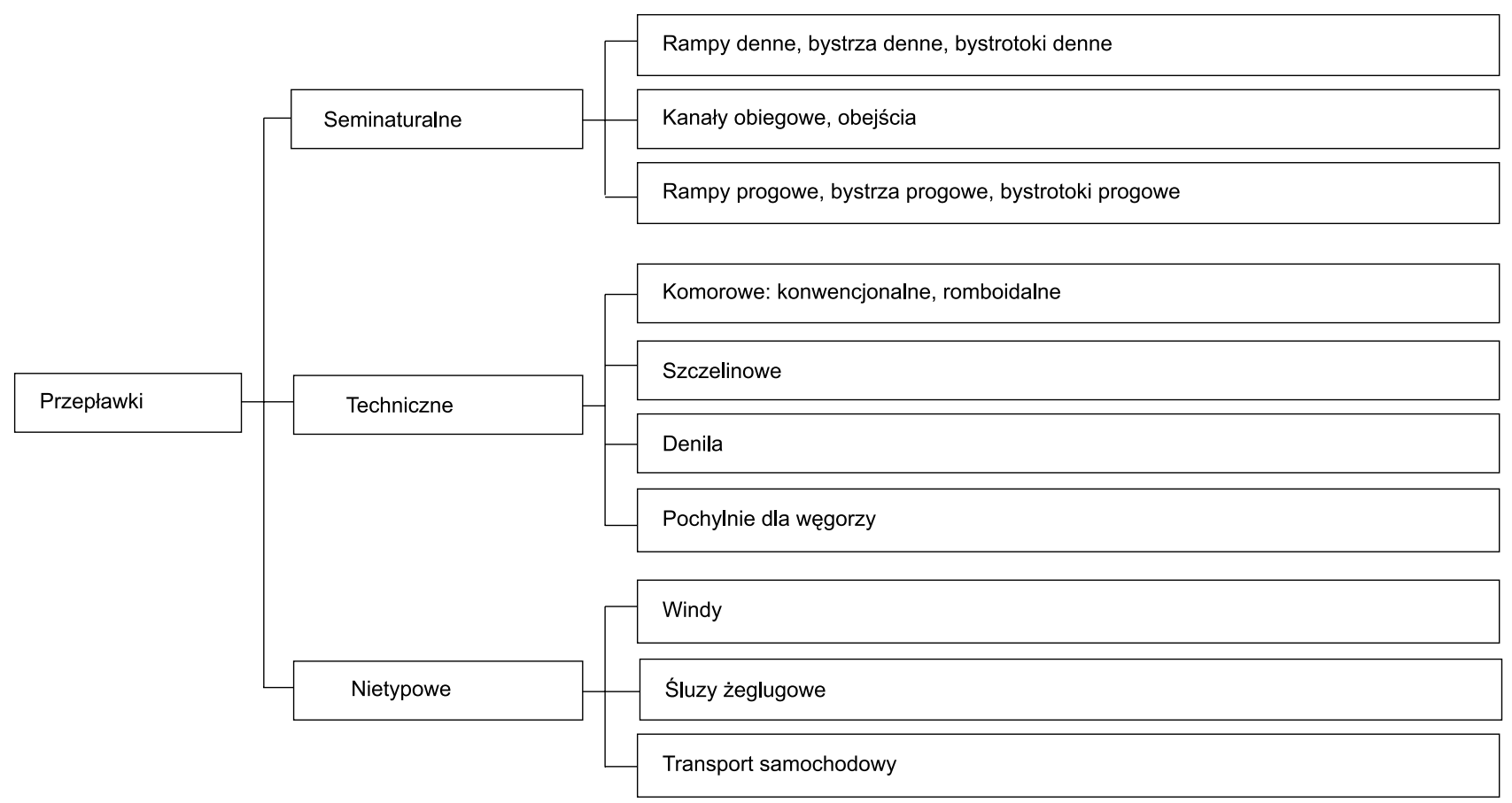

Ryc. 2. Ogólny podział przepławek według DVWK (2002), zmienione

Fig. 2. Fishpasses general systematic by DVWK (2002), modified 
wania formalnoprawne powinny uwzględniać zarówno poziom europejski (np. dyrektywa ptasia i siedliskowa), poziom krajowy (np. program wodno-środowiskowy kraju), poziom regionalny (np. plany gospodarowania wodami na obszarach dorzeczy), poziom lokalny (np. miejscowy plan zagospodarowania przestrzennego gminy) oraz plany ochrony obszarów chronionych (np. Natura 2000). Analiza uwarunkowań środowiskowych winna zawierać charakterystykę ichtiologiczną w zlewni, i to zarówno współczesną, jak i historyczną oraz planowaną w przyszłości obejmującą m.in. okresy i warunki migracji, okresy i warunki tarła, warunki bytowania czy możliwości pływackie, charakterystykę hydrologiczną rzeki, w tym m.in. stany i przepływy typowe, o określonym czasie trwania, o określonym prawdopodobieństwie przekroczenia, konwencjonalne, oraz charakterystykę morfologiczną zlewni i rzeki, obejmującą m.in. opis koryta, strukturę zlewni i koryta, materiał dna, zagospodarowanie zlewni, zmiany wywołane piętrzeniem, wpływ antropopresji. Z kolei uwarunkowania techniczne winny obejmować charakterystykę stopnia, m.in. zadania stopnia, jego infrastrukturę (np. MEW), działanie (np. gospodarowanie wodą), warunki hydrauliczne przepływu wody itp. Analiza różnych wariantów udrożnienia stopnia winna zawierać przede wszystkim wariant likwidacji piętrzenia, w następnej kolejności rozwiązanie seminaturalne, dalej techniczne i nietypowe. Nie bez znaczenia pozostaje jakość opracowania projektu oraz wykonania urządzenia, a także jego użytkowanie. Często pomijanym aspektem jest konieczność wprowadzania zmian i korekt w pracy urządzenia, które na podstawie obserwacji mogą się okazać niezbędne w celu poprawy efektywności działania.

\section{Literatura}

Bylak A., Kukuła K., Kukuła E., 2009. Influence of regulation on ichthyofauna and benthos of the Różanka stream. Ecohydrology \& Hydrobiology 9: 211-223.
DVWK (Deutscher Verband für Wasserwirtschaft und Kulturbau), 2002. Fish passes - Design, dimensions and monitoring. FAO, Rome.

Dysarz T., Wicher-Dysarz J., Przedwojski B., Wierzbicki M., 2006. Wpływ zabudowy oraz procesów morfodynamicznych na transformację reżimu hydrologicznego w cofkowej części zbiornika Jeziorsko na rzece Warcie. Infrastruktura i Ekologia Terenów Wiejskich 4: 213-222.

Klimaszewski M., 2005. Geomorfologia. Wydawnictwo Naukowe PWN, Warszawa.

Kondolf G.M., 1997. Hungry water: effects of dams and gravel mining on river channels. Environmental Manage 21: 533-551.

Kukuła K., 2001. Ichtiofauna górnego Sanu. Referat w PTH Kraków, 15.04.2011.

Lessard J.L., Hayes D.B., 2003. Effects of elevated water temperature on fish and macroinvertebrate communities below small dams. River Research and Applications 19(7): 721-732.

Popek Z., 2006. Warunki ruchu rumowiska wleczonego w małej rzece nizinnej. Wydawnictwo SGGW, Warszawa.

Przedwojski B., 1998. Morfologia rzek i prognozowanie procesów rzecznych. Wydawnictwo Akademii Rolniczej im. Augusta Cieszkowskiego w Poznaniu, Poznań.

Przedwojski B., Dysarz T., Wicher-Dysarz J., Wierzbicki M., 2008. Analiza wpływu czynników morfodynamicznych i wegetacyjnych na kształtowanie warunków hydraulicznych w cofkowej części nizinnych zbiorników wodnych. Monografia. Uniwersytet Przyrodniczy w Poznaniu, Poznań.

Przedwojski B., Wierzbicki M., Wicher-Dysarz J., Walczak N., 2007. Stan zagrożenia powodziowego powyżej zbiornika Jeziorsko. Nauka, Przyroda, Technologie 1(2): 229-240.

Radecki-Pawlik A., 2011. Hydromorfologia rzek i potoków górskich. Wydawnictwo Uniwersytetu Rolniczego w Krakowie, Kraków.

Radke G., Bernaś R., Skóra M., 2012. Małe elektrownie wodne - duże problemy ekologiczne: przykłady z rzek północnej Polski. Chrońmy Przyrodę Ojczystą 68(6): 424-434.

Verspoor E., 1997. Genetic diversity among Atlantic salmon (Salmo salar L.) populations. ICES Journal of Marine Science 54: 965-973.

Wierzbicki M., Hammerling M., Przedwojski B., 2008. Przebieg procesu erozji poniżej zbiornika Jeziorsko na rzece Warcie. Przegląd Naukowy Inżynieria i Kształtowanie Środowiska XVII 2(40): 136-145.

Wierzbicki M., Wicher J., 2002. Wpływ erozji poniżej zbiornika Jeziorsko na zmiany zachodzące w korycie rzeki Warty. Przegląd Naukowy Inżynieria i Kształtowanie Środowiska XI 2(25): 91-102.

Wiśniewolski W., Mokwa M., Zioła S., 2008. Migracje ryb - przyczyny, zagrożenia i możliwości ochrony. Monografia. Dolnośląskie Wydawnictwo Edukacyjne, Wrocław. 